\title{
Continued implication of the banned pesticides carbofuran and aldicarb in the poisoning of domestic and wild animals of the Canary Islands (Spain)
}

\author{
Norberto Ruiz-Suárez a , Luis D. Boada a , Luis A. Henríquez-Hernández ${ }^{\text {a }}$, Federico González-Moreo ${ }^{\text {b }}$, \\ Alejandro Suárez-Pérez ${ }^{\mathrm{b}}$, María Camacho ${ }^{\mathrm{a}, \mathrm{b}}$, Manuel Zumbado a ${ }^{\text {a }}$ Maira Almeida-González ${ }^{\mathrm{a}}$, \\ María del Mar Travieso-Aja ${ }^{\text {a }}$ Octavio P. Luzardo ${ }^{\mathrm{a}, \mathrm{b}, *}$ \\ a Clinical and Analytical Toxicology Service (SERTOX), University of Las Palmas de Gran Canaria, Plaza Dr. Pasteur s/n. 35016 Las Palmas de Gran Canaria, Spain

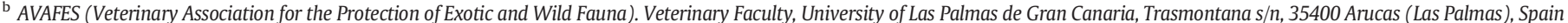

\section{H I G H L I G H T S}

- Report of pesticide poisoning of animals in the Canary Islands (Spain)

- 225 animals poisoned, intentionality confirmed in $52 \%$ of cases

- Frequent involvement of protected wild species

- The highest incidence of poisoning reported in any region from European Union

- European Union's banned pesticides identified in $75 \%$ of animals

\section{A R T I C L E I N F O}

\section{Article history:}

Received 27 September 2014

Received in revised form 26 October 2014

Accepted 26 October 2014

Available online 11 November 2014

Editor: D. Barcelo

\section{Keywords:}

Banned pesticides

Intentional poisoning

Carbofuran

Aldicarb

Poisoning

\begin{abstract}
A B S T R A C T
Although nowadays the intentional poisoning of domestic and wild animals is a crime in EU, in the past the poison was used in rural areas of a number of European countries to kill animals that were considered harmful for human activities. In Spain evidences indicate that intentional poisonings continue to occur throughout the entire country nowadays. This situation seems to be of particular concern in the Canary Islands (Spain), where this study was performed. Our results confirmed that 225 animals were poisoned by pesticides over the study period (32 months; 2010-2013). The intentionality of the poisoning was confirmed in 117 cases. It has to be highlighted that the other 108 animals also died by pesticide poisoning, although the intentionality was only suspected. This incidence is currently the highest reported in any region from European Union. The pesticides carbofuran, bromadiolone, brodifacoum and aldicarb were the most frequently detected involved. Among the affected species, it has to be highlighted that endangered species are frequently affected in poisoning incidents. Notably, chemicals banned in the EU (carbofuran and aldicarb) were identified in approximately $75 \%$ of cases, and in almost $100 \%$ of baits, which suggests that these pesticides are still available to the population. Several circumstances may explain these results. Firstly, little control over the sale and possession of pesticide products, and the potential existence of an illegal market of pesticides banned in the European Union in the neighbouring African continent. In addition, the limited awareness of the population about the dangerousness of these compounds, for the environment, animals, or even people, make the situation very worrying in these islands. Stronger regulations, control of legal and illegal pesticide use, development of educational programs and legal action in poisoning incidents are needed to decrease the impact of pesticide misuse on wildlife and domestic animals.
\end{abstract}

C 2014 Elsevier B.V. All rights reserved.
* Corresponding author at: Toxicology Unit, Department of Clinical Sciences, University of Las Palmas de Gran Canaria, Plaza Dr. Pasteur s/n. 35016 Las Palmas de Gran Canaria, Spain. Tel.: + 34928451 424; fax: + 34928451461 .

E-mail address: operez@dcc.ulpgc.es (O.P. Luzardo).

\section{Introduction}

It is well documented that agricultural pesticides cause a large number of accidental poisonings in target and non-target species. In the literature it has been described that wild animals are particularly 
affected by accidental pesticide exposure (Berny, 2007; Berny and Gaillet, 2008; Guitart et al., 1999; Kwon et al., 2004; Martínez-Haro et al., 2008; Ogada, 2014; Slaninova et al., 2009; Wagner et al., 2013); additionally, domestic animals (Berny et al., 2010; Guitart et al., 2010a; Hornfeldt and Murphy, 1997), and humans are frequently poisoned by pesticides (Eddleston et al., 2002; Litchfield, 2005). However the situation is even worst when pesticides are used intentionally to kill animals, mainly through the use of poisoned baits. Of the chemicals that baits can be laced with, pesticides are commonly used (Brown et al., 2005; Ogada, 2014). It has been estimated that pesticides are used illegally in up to $68 \%$ of all suspected poisoning animal cases (Berny, 2007). Epidemiological studies revealed that pesticides account for approximately $52.5 \%$ of bird poisonings and that pesticides are a major cause of wild mammal deaths (Guitart et al., 2010b). Because of their high toxicity, several restrictions have been applied to many compounds that are currently banned or severely restricted in the EU (EC, 2003, 2006).

The use of poisoned baits is an illegal, massive, non-selective method affecting many species, in addition to those against whom they are directed. Its use is a serious threat to public health and biodiversity in Europe. In the EU, this illegal practice represents one of the biggest conservation problems for some endangered species, often becoming the main cause of non-natural death. Currently intentional poisoning is an act of animal cruelty and a criminal offense in the European legislation.

In Spain and other Mediterranean countries, where conflicting rural uses may motivate the illegal use of poisoned baits, the problem is particularly serious. Although the current Spanish legislation condemns and prosecutes the use of poisoned baits, this practice has been legally used (and even promoted) to eliminate animals in Spain over the past century (BOE, 1953). Thus, the poison was used in rural areas to kill animals that were considered harmful for different activities, including hunting, farming, agriculture, pigeon breeding or apiculture (De la Bodega, 2012). In addition, poisoned baits were used in urban areas against stray cats and dogs. Due to such circumstances, the habit of using poisoned baits is deeply rooted in the population and is not perceived as a serious risk, even currently, in rural areas.

Currently, no governmental body in Spain can provide reliable statistics on the actual incidences of animal poisoning. However, various reports have examined the effects of poisons on endangered wildlife populations (González et al., 2007; Hernandez and Margalida, 2008; Hernández and Margalida, 2009; Margalida et al., 2008). Moreover, veterinary toxicology services from several universities have published statistics indicating that animal poisoning remains a common practice in Spain (Berny et al., 2010; Guitart et al., 1999; Motas-Guzman et al., 2003). Many poisoning cases were caused by strychnine (rodenticide) until the year 2000, when its use was prohibited (Hernandez and Margalida, 2008), whereas from 2000 to 2007, most primary and secondary poisoning cases were caused by anticholinesterase agents, mainly aldicarb and carbofuran, and by anticoagulant rodenticides (Fajardo et al., 2012; Guitart et al., 1999; Hernandez and Margalida, 2008; Martínez-Haro et al., 2008; Motas-Guzman et al., 2003). In the $\mathrm{EU}$, the marketing of products containing aldicarb was withdrawn in 2003 (EC, 2003), and products containing carbofuran in 2007 (EC, 2007). Therefore, a reduction in poisoning episodes involving these substances should be expected. However, studies on other compounds indicate that legal and commercial restrictions have not influenced the intentional illegal use of these substances as poisons (Kervegant et al., 2013; Martínez-Haro et al., 2008).

In our laboratory, samples poisoning of wild and domestic animals are received since 2003. Our preliminary evidence indicated that pesticides were often involved in poisoning episodes, and in many cases there was also evidence of the intention thereof, with the use of banned substances. With these antecedents in mind, we planned this study in which samples of all cases of poisoning of animals detected in the Canary Islands since the beginning of 2010 were taken for chemical analysis. A careful and systematic collection of all data of each episode was performed. Our main objective was to test the hypothesis that in this archipelago exists a continued use of pesticides banned in the EU for the intentional poisoning of wildlife. This paper presents and discusses the results of those cases where intentional poisoning was suspected initially, and also those cases of poisoning of unknown origin. Cases of accidental poisoning with a clear accidental origin were expressly excluded. The collection of cases lasted for a period of 32 months. Our results have confirmed a high incidence of intentional illegal poisoning in this region as well as the continued use of pesticides that were banned in the EU for several years.

\section{Materials and methods}

\subsection{Sampling and ethics statement}

We analysed 544 samples (tissues and baits) from 188 poisoning cases that involved the death of 225 animals. The number of animals involved per incident ranged from 1 to 14 . Samples analysed included liver, blood, stomach contents, vomiting, brain, kidney, flesh and bones, and plastic containers. Investigated animals belonged to 14 different species (187 dogs and cats, 22 reptiles, 75 raptors/scavengers, 11 wild mammals, and 11 wild non-raptor birds). Sampling was performed between January 2010 and September 2013 in the Wildlife Recovery Centres (WRCs) and the Veterinary Hospital of the Veterinary Faculty of the ULPGC, where clinical veterinary facilities of the Canary archipelago submitted cases for analyses. During the necropsy samples were collected and kept frozen $\left(-20^{\circ} \mathrm{C}\right)$ until they were submitted to the Service of Clinical and Analytical Toxicology (SERTOX) of the University of Las Palmas de Gran Canaria (ULPGC, Canary Islands, Spain), where remained frozen at the same temperature until analysis. Most animals were found dead in the countryside or urban areas or died while at veterinary facilities. No animals were killed for the purposes of this study, and no experiments were performed on or with samples from living animals.

\subsection{Data selection}

Circumstantial, medical and pathological records of all suspected animal poisoning cases submitted to the SERTOX were reviewed. Only cases in which one or more pesticides were identified in samples from animals (mainly blood, liver, brain or gastric contents), and these pesticides were quantified at a concentration considered toxic for that species (http://toxnet.nlm.nih.gov/), were considered positive cases for this study. We also included in this study all those baits, which were suspicious to have been laced with toxic substances. Data analysis included the time and location of the poisoning, seasonality, type of species, number of animals affected, and pesticide(s) detected. A major challenge in this type of cases is to distinguish whether they are intentional or accidental poisonings. For this task we have had the help of the veterinary experts from the WRCs of the Canary Islands. The veterinary assessment of the potential intentionality was based on: a) visualization of abnormal substances, baits or materials and identification of possible exposure route or method of administration; b) estimate of time of exposure to the toxic, based on the progression of physical symptoms or physiological changes; c) direct evidence of intentionality, such as remains of bait or unusual food items in the mouth, stomach contents or vomit; d) exclusion of potential natural or accidental poisoning sources. Besides the above, the veterinarians gave a written report about pain or possible animal suffering associated with a particular poison, which may be necessary to file animal cruelty charges against the perpetrator. In many cases environmental protection agents of the Government of the Canary Islands or officers of the Service of Nature Protection of the Police (Guardia Civil) conducted the forensic investigation of the crime scene to provide additional evidences of poisoning. On the basis of all the above, the cases were initially classified as: a) allegedly intentional poisoning; b) poisoning of unknown origin; c) accidental poisoning. These latter cases were excluded from this study. 


\subsection{Chemical analyses}

Procedure for the extraction, purification and quantification of pesticides in samples from animal poisoning incidents have been fully validated in our laboratory and previously published (Luzardo et al., 2014). This procedure was developed for the quantification of 117 pesticides, which were selected because of their high toxicities in animals or their frequent use in animal poisonings (Table 1) (Berny, 2007; Berny et al., 2010; De la Bodega, 2012; Mineau et al., 2001). Briefly, the samples ( $2 \mathrm{~g}$ ) were subjected to a solid-extraction with $10 \mathrm{ml}$ of a mixture of dichloromethane/ethyl acetate/acetone (50/30/20) followed by one (gel permeation chromatography, GPC) or two purification steps for highly degraded matrices (GPC plus freezing centrifugation). The purified extract was divided into two aliquots that were re-dissolved in cyclohexane and acetonitrile prior to chromatographic analyses. We used a Thermo Trace GC Ultra with split/splitless injector for the chromatographic analyses coupled to a triple quadrupole TSQ XLS mass spectrometer (Thermo Fisher Scientific Inc., USA) for the analysis of 91 non-polar pesticides, using a column of $30 \mathrm{~m} \times 0.25 \mathrm{~mm}, 0.25 \mu \mathrm{m}$ film thickness (BPX5, SGE Inc., USA) as the stationary phase and helium (99.999\%) as the carrier gas. A timed selected reaction monitoring (t-SRM) method was constructed to analyze all the target compounds plus ISs in a single run (61 min). The most polar pesticides were analysed by two complementary methods using a Thermo LC Accela Ultra instrument coupled to a TSQ Quantum Max triple quadrupole mass spectrometer (Thermo Fisher Scientific Inc., USA). An analytic Accucore C18 column $(2.6 \mu \mathrm{m}, 150 \times 3 \mathrm{~mm}$; Thermo Fisher Scientific Inc., USA) was used for the separation of anticoagulant rodenticides, and an analytic Synergi Hydro-RP column $(4.0 \mu \mathrm{m}, 150 \times 4.6 \mathrm{~mm}$; Phenomenex, Torrance, USA) was used for the analysis of the rest of polar pesticides. A t-SRM method was contructed by directly infusing pure standard methanolic solutions into the source to analyze 26 target compounds plus ISs in two separate runs. The calibration curve ranged from 0.5 to $500 \mathrm{ng} / \mathrm{mL}$ and included all of the compounds in each calibration standard level. The quantification was performed by the internal standard method. An example can be found in Supplementary Fig. 1. In each batch of samples, three controls were included: a reagent blank consisting of a vial containing only cyclohexane and two internal laboratory quality controls (QC) consisting of melted meat fat and chicken liver, both spiked at $20 \mu \mathrm{g} / \mathrm{kg}$ of each of the analytes, which were processed using the same method as the samples. The batch analyses were considered valid when the values of the analytes in the QC were within a $10 \%$ of deviation of the theoretical value. All the details of the methodology and validation procedure can be found in Luzardo et al. (2014).

\subsection{Statistical analysis}

Database management and statistical analysis were performed with the PASW Statistics v 17.0 statistical software (SPSS Inc., Chicago, IL,

Table 1

Toxicities of the pesticides included in the screening.

\begin{tabular}{|c|c|c|c|c|c|c|c|c|}
\hline \multirow[b]{2}{*}{ Compound } & \multicolumn{2}{|l|}{ Toxicity $^{a}$} & \multirow[b]{2}{*}{ Compound } & \multicolumn{2}{|l|}{ Toxicity $^{a}$} & \multirow[b]{2}{*}{ Compound } & \multicolumn{2}{|l|}{ Toxicity $^{a}$} \\
\hline & $\mathrm{LD}_{50 \text { birds }}$ & $\mathrm{LD}_{50 \text { mammals }}$ & & $\mathrm{LD}_{50 \text { birds }}$ & $\mathrm{LD}_{50 \text { mammals }}$ & & $\mathrm{LD}_{50 \text { birds }}$ & $\mathrm{LD}_{50 \text { mammals }}$ \\
\hline Acephate & 125.0 & 321.0 & Dichlorphos & 8.8 & 61.0 & Metolcarb & 100.0 & 109.0 \\
\hline Aldicarb & 3.8 & 1.9 & Dicrotophos & 1.2 & 11.0 & Metomil & 20.5 & 24.9 \\
\hline Aldrin & 7.2 & 65.0 & Dieldrin & 13.3 & 65 & Mevinphos & 1.4 & 4.0 \\
\hline Allethrin & 2030.0 & 370.0 & Difenacoum & 50.0 & 50.0 & Monocrotophos & 0.8 & 15.0 \\
\hline Amitraz & - & 100.0 & Difethialone & 0.9 & 4.0 & Nuarimol & 200.0 & 2450.0 \\
\hline Azinphos ethyl & 34.4 & 12.0 & Dimefox & 1.7 & 3.5 & Omethoate & 125.0 & 50.0 \\
\hline Azinphos methyl & 8.5 & 10.0 & Dimethoate & 45.6 & 220.0 & Oxamyl & 4.2 & 30.0 \\
\hline Bendiocarb & 21.0 & 35.0 & Dioxathion & 200.0 & 10.0 & Parathion ethyl & 1.3 & 0.9 \\
\hline Benfuracarb & 92.0 & 102.0 & Disulfoton & 2.4 & 5.0 & Parathion methyl & 5.0 & 57.0 \\
\hline Bifenthrin & 1975.0 & 54.5 & Ediphenphos & 350.0 & 100.0 & Phenthoate & 58.6 & 138.0 \\
\hline Brodifacoum & 4.5 & 2.5 & Endosulfan sulphate & 52.4 & 18.0 & Phorate & 1.0 & 20.0 \\
\hline Bromadiolone & 138 & 16.5 & Endosulfan, alpha & 35.0 & 26.0 & Phosalone & - & 112.0 \\
\hline Bromophos ethyl & 20.5 & 125.0 & Endosulfan, beta & 35.0 & 26.0 & Phosmet & 18.0 & 40.0 \\
\hline Bromoxynil & 50.0 & 78.0 & Endrin & 1.7 & 3.0 & Phosphamidon & 1.8 & 6.0 \\
\hline Cadusafos & 16.0 & 71.4 & EPN & 2.4 & 20.0 & Phoxim & 5.6 & 250 \\
\hline Carbaryl & 56.0 & 150.0 & Ethion & 45.0 & 13.0 & Pirimicarb & 45.5 & 100.0 \\
\hline Carbofuran & 22.4 & 10.2 & Etoprophos & 4.2 & 34.0 & Pirimiphos ethyl & 3.0 & 25.0 \\
\hline Carbophenothion & 5.8 & 14.0 & Famphur & 1.8 & 59.0 & Pirimiphos methyl & 30.0 & 1150.0 \\
\hline Carbosulfan & 120.0 & 115.0 & Fenamiphos & 2.4 & 10.0 & Profenofos & 1.9 & 116.0 \\
\hline Carboxin & 42.2 & 430.0 & Fenitrothion & 11.0 & 142.0 & Propachlor & 91.0 & 392.0 \\
\hline Chlordane, cis & 220.0 & 50.0 & Fensulfothion & 0.3 & 2.2 & Propaphos & 2.5 & 61 \\
\hline Chlordane, trans & 220.0 & 50.0 & Fenthion & 1.4 & 46.2 & Propetamphos & 49.0 & 130.0 \\
\hline Chlorfenvinphos & 13.0 & 20.0 & Flucythrinate & 2708.0 & 76.0 & Propoxur & 19.9 & 51.2 \\
\hline Chlormephos & 65.0 & 12.5 & Fonofos & 10.0 & 3.0 & Pyrazophos & 118.0 & 184.0 \\
\hline Chlorophacinone & 430.0 & 7.5 & Formothion & 630.0 & 175.0 & Quinalphos & 20.0 & 75.0 \\
\hline Chlorpyrifos & 5.2 & 60.0 & Heptachlor & 125.0 & 50.0 & Resmethrin & 75.0 & 250.0 \\
\hline Chlorpyriphos methyl & 13.0 & 2000.0 & Heptenophos & 17.0 & 117.0 & Sulfotep & 25.0 & 22.0 \\
\hline Chlorthiophos & 45.0 & 20.0 & Imidacloprid & 152.0 & 98.0 & Sulprofos & 65.0 & 70.0 \\
\hline Cifluthrin & 250.0 & 300.0 & Isazophos & 244.0 & 27.0 & Tebufenpyrad & 2000.0 & 210.0 \\
\hline Coumatetralyl & 38.3 & 42.5 & Isobenzan & 1.0 & 5.0 & Tefluthrin & 267.0 & 22.0 \\
\hline Cyanazine & 400.0 & 141.0 & Isofenphos & 3.0 & 91.5 & TEPP & 1.3 & 2.3 \\
\hline Cyanophos & 3.0 & 215.0 & Isoxathion & 21.6 & 112.0 & Terbufos & 15.0 & 3.5 \\
\hline Cyproconazole & 150.0 & 352.0 & Leptophos & 268.8 & 65.0 & Tetrachlorvinphos & 100.0 & 4200.0 \\
\hline Dazomet & 424.0 & 415.0 & Lindane & 127.0 & 25.0 & Thiometon & 100.0 & 37.0 \\
\hline DDT & 1135.0 & 200.0 & Malathion & 400.0 & 53.0 & Thionazin & 2.4 & 5.0 \\
\hline Deltamethrin & 1000.0 & 22.0 & Mephospholan & 2.8 & 11.0 & Triazophos & 4.2 & 57.0 \\
\hline Diallate & 167.0 & 395.0 & Metamidofos & 14.3 & 18.5 & Trichloronat & 1.6 & 10.0 \\
\hline Diazinon & 2.0 & 76.0 & Methidathion & 80.0 & 25.0 & Warfarin & 942.0 & 6.5 \\
\hline Dichlone & - & 160.0 & Methiocarb & 2.4 & 16.0 & & & \\
\hline
\end{tabular}

a Average data from different species. These data have been taken from Mineau et al. (2001) and the National Library of Medicine internet resources ChemIDplus (http:// chem.sis.nlm.nih.gov/chemidplus/chemidheavy.jsp) and Hazardous Substances Data Bank (http://toxnet.nlm.nih.gov/cgi-bin/sis/htmlgen?HSDB). 
USA). Kolmogorov-Smirnov test was employed for testing the normality of the distribution of the variables. Differences between variables were performed using Student's t-test. Categorical variables (percentages) were compared by the chi-squared test. P values $<0.05$ (two-tailed) were considered to be statistically significant.

\section{Results}

We finally included in this study 455 samples from 225 deceased animals and 24 baits. 117 animals were initially classified as having been poisoned on purpose according the veterinary services. The rest (108 animals) could not be initially classified nor as intentionally nor as accidentally poisoned. All the baits were initially classified as intentionally delivered in the environment. The number of deceased animals in cases where a pesticide was detected at toxic concentrations (Mineau et al., 2001) (Table 1) was significantly higher than from negative cases, this is, cases where no pesticide was detected (mean $2.73 \pm 0.31$ vs. $1.82 \pm 0.22, P<0001)$.

The species of domestic animals affected included cats (number of pesticide-poisoned/analysed animals, $n=84 / 103$ ), and dogs ( $\mathrm{n}=42 / 84$ ). The wildlife species involved in suspicious poisoning incidents included Eastern Canaries lizards (Gallotia stehlini, $\mathrm{n}=22 / 22$ ), common buzzards (Buteo buteo $=16 / 20$ ), European turtle doves (Streptopelia turtur, $\mathrm{n}=9 / 11$ ), common ravens (Corvus corax $=13 / 16$ ), European hedgehogs (Erinaceus europaeus $=11 / 11$ ), common kestrels (Falco tinnunculus, $\mathrm{n}=15 / 17$ ), barn owls (Tyto alba, $\mathrm{n}=8 / 9$ ), long-eared owls (Asio otus, $\mathrm{n}=5 / 6$ ), Egyptian vultures (Neophron percnocterus, $\mathrm{n}=0 / 3$ ), and Barbary falcons (Falco pelegrinoides, $\mathrm{n}=4 / 4$ ). In addition, pesticides were detected in $81.82 \%$ of 24 baits (meat, fish, bones and flesh, bread, milk, or plastics and containers). The pesticides that have been detected in each species or the baits are presented in Table 2 .

Pesticides were present in $61.34 \%$ of the analysed cases $(76.47 \%$ of the animals submitted for testing). Fourteen different pesticides were detected with a mean of $1.23 \pm 0.58$ pesticides per incident. The chemicals most frequently detected were carbofuran $(43.12 \%$ of the incidents, $\mathrm{n}=119$ dead animals), bromadiolone (13.62\%, $\mathrm{n}=18$ ), aldicarb $(12.23 \%, n=51)$, and brodifacoum $(10.56 \%, n=17)$. The other pesticides were oxamyl $(8.32 \%, \mathrm{n}=11)$, methomyl $(8.43 \%, \mathrm{n}=19)$, difenacoum $(6.85 \%, \mathrm{n}=10)$, carboxin $(4.07 \%, \mathrm{n}=9)$, chlorpyrifos $(3.11 \%, \mathrm{n}=7)$, diazinon $(2.04 \%, \mathrm{n}=4)$, fenthion $(2.04 \%, \mathrm{n}=3)$, propoxur $(1.81 \%, n=2)$, fenazaquin $(0.90 \%, n=2)$, and fipronil $(0.90 \%, n=1)$.
No significant differences in the toxic concentrations of any of the pesticides among species were found. However we found a highly significant relationship between the number of dead animals and the pesticide involved. The most lethal pesticides in our study were aldicarb and carbofuran, which involved the death of $3.92 \pm 0.78$ and $2.52 \pm 0.46$ animals per incident, respectively $(P<0.01)$. We also found that Eastern Canaries lizard and domestic cat were the species where higher number of individuals died per incident $(6.11 \pm 1.82$ and $3.76 \pm 1.25$ animals per incident respectively).

Interestingly, four of the 14 pesticides detected were banned products in the EU, including aldicarb, carbofuran, diazinon, and fenthion. Carbofuran and aldicarb were responsible for the death of approximately $75 \%$ of the animals from positively identified cases (Fig. 1). These pesticides were detected in the baits and in domestic and wild animals (Table 2). We considered very relevant the fact that $93.75 \%$ of positive baits had been laced with either carbofuran or aldicarb (Fig. 1, and Table 2). It was also considered very relevant that in $97.43 \%$ of the cases that were initially classified as intentionally poisoned pesticides were positively identified and quantified at levels that revealed the substance was the cause of the death. Moreover in 103 of these 117 animals (88.03\%) the compound detected was a banned substance (carbofuran, aldicarb or diazinon).

We have to note that all of the species were not affected by pesticides identically. Cats, dogs, and wildlife species such as Eastern Canaries lizards, European hedgehogs and common buzzards were significantly affected by banned pesticides $(P<0.005)$. On the contrary, the nocturnal birds of prey (barn owls and long-eared owls) were mainly affected by products that are legal in the EU (anticoagulant rodenticides, $P<0.01$ ).

\section{Discussion}

We report in this work the relevance of pesticide poisoning as a cause of death in domestic animals and wildlife in the Canary Islands (Spain) according to data obtained from SERTOX. Our results indicate that the incidence of intentional poisonings in this archipelago is very high, probably higher than that of other European regions.

It has to be highlighted that products that were banned several years ago were involved in a significant percentage of the cases. Notably, the involvement of chemicals banned in the EU (such as carbofuran and aldicarb) in the death of animals does not seem to be decreasing as expected.

Table 2

Identification of pesticides in animals and baits from poisoning episodes occurred in the Canary Islands during the period $2010-2013$.

\begin{tabular}{|c|c|c|c|c|c|}
\hline & \multicolumn{5}{|c|}{ Principal toxicant(s) } \\
\hline & Carbofuran & Aldicarb & Other AcHE Inhibitors & Anticoag. & Others \\
\hline \multicolumn{6}{|l|}{ Wild animals } \\
\hline Eastern Canaries Lizard (Gallotia galloti) & 6 & 16 & & & \\
\hline Barn Owl (Tyto alba) & & & & 8 & \\
\hline Common Kestrel (Falco tinnunculus) & 3 & 4 & 3 & 4 & 1 \\
\hline Long-eared Owl (Asio otus) & 1 & & & 4 & \\
\hline Common Buzzard (Buteo buteo) & 9 & 3 & 2 & 1 & \\
\hline European Hedgehog (Erinaceus europaeus) & 11 & & & & \\
\hline Common Raven (Corvus corax) & 8 & & 5 & & \\
\hline European Turtle-dove (Streptopelia turtur) & & & & 4 & 6 \\
\hline Barbary Falcon (Falco pelegrinoides) & 1 & & 2 & 1 & 2 \\
\hline Eurasian Coot (Fulica atra) & 1 & & & & \\
\hline Long-eared Bat (Plecotus teneriffae) & & & & & 2 \\
\hline \multicolumn{6}{|l|}{ Domestic animals } \\
\hline Cats & 59 & 7 & 16 & 1 & \\
\hline Dogs & 12 & 19 & 7 & 4 & \\
\hline Goat & & & & & 1 \\
\hline \multicolumn{6}{|l|}{ Baits and suspicious materials } \\
\hline Meat & 3 & 1 & & & \\
\hline Feed & 3 & & 1 & & \\
\hline Bones and flesh & 1 & 3 & & & \\
\hline Other & 4 & & & & \\
\hline
\end{tabular}




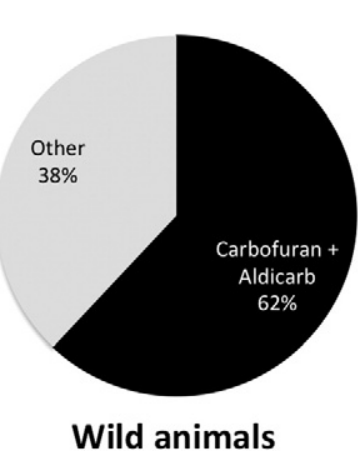

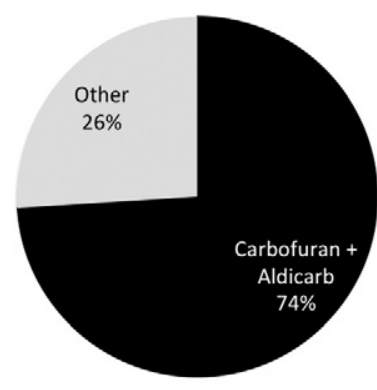

Domestic animals

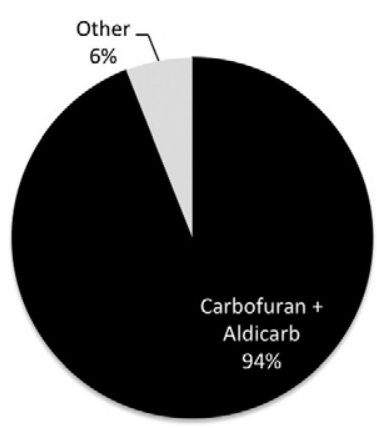

Baits

Fig. 1. Frequency of the implication of carbofuran and aldicarb in the animal poisoning incidents.

Because this practice is greatly harmful to biodiversity as well as an important public health problem, it is necessary that authorities enact effective measures on the marketing of toxic chemicals, control of banned chemical stocks, the implementation of educational programs, and effective criminal prosecution of poisoners to prevent, or at least minimise, the incidence of this harmful practice.

The high incidence of pesticide poisoning cases in this territory, and the high mortality of the exposed animals are remarkable. The data presented here are much higher than other results published in Europe (Guitart et al., 1999; Motas-Guzman et al., 2003), which reported far fewer cases per year. However, there are no official animal poisoning records, and recent information from many regions is lacking. From the literature it can be assumed that the figures reported in those studies only represent an approximation of the actual incidence of wildlife mortality because it has been estimated that less than $10 \%$ of poisoning cases are detected and sent to a forensic laboratory (De la Bodega, 2012; Guitart et al., 1999). This is especially relevant for wildlife because sick animals often become less visible and many die in nests, burrows or inaccessible places. Nevertheless, our findings indicate that the actual incidence of mortality from poisoning in the Canary Islands is very high and undoubtedly higher than that of other European regions.

It has drawn our attention that the percentage of cases in which there was evidence of intentional poisoning was very high in the Canary Islands, as we confirmed the presence of a pesticide at toxic levels in the great majority of the cases that were initially classified as intentional poisonings by the veterinary services. Notably, substances that were banned several years ago were detected in approximately $75 \%$ of the positive cases, and this percentage raised to almost $90 \%$ in the cases classified as intentional poisonings, and to almost $100 \%$ in the baits. In Spain and other Western countries, these highly toxic products have been often involved in poisonings, but the references are dated prior to the permanent ban of these pesticides (Guitart et al., 1999; Hernandez and Margalida, 2008; Hernández and Margalida, 2009; Motas-Guzman et al., 2003). After the ban of other pesticides, such as strychnine (Hernandez and Margalida, 2008) or paraquat (Kervegant et al., 2013), poisonings continued for several years because stocks of these chemicals that had been acquired before the prohibition were illegally used until the supply was exhausted. Nevertheless, the incidence of poisoning with these banned chemicals has exhibited a progressive decreasing yearly trend each year until ultimately ceasing to occur (Hernandez and Margalida, 2008; Kervegant et al., 2013). According to our data, the opposite situation is occurring in the Canary Islands because an increased incidence in animal poisonings with carbofuran, aldicarb, and other banned compounds (such as diazinon and fenthion) has been detected. The reasons for these findings are not clear; however, in a recent study, some companies agreed to the sale of banned substances when the authors attempted to purchase $5 \mathrm{~g}$ on the internet, which demonstrates the existence of an illegal market of banned pesticides (De la Bodega, 2012) that may also be present in the Canaries.

Carbofuran and aldicarb are granular insecticides that were banned throughout the European Union (EC, 2003, 2007) because of their high toxicity, low handling safety and ecotoxicological effects. Table 3 presents the "potential of lethality" for these compounds, which indicates the number of different animal species that would theoretically die with $5 \mathrm{~g}$ of product, based on the $\mathrm{LD}_{50}$ value and average body weight for each species (De la Bodega, 2012). Both pesticides have been widely used in the agricultural sector of the Canary Islands, including in the cultivation of banana (carbofuran) and vegetable crops (aldicarb); therefore, significant amounts of obsolete product may be present in private farms that have not been destroyed and could be motivating their intentional use against domestic and wild fauna. In addition to the existing market in internet, an illegal market for these chemicals may exist in the neighbouring African continent where a number of highly toxic pesticides are still permitted (De la Bodega, 2012).

Various reasons have been proposed to explain why pesticides, and poisons in general, have been used to kill animals indiscriminately. When analysing the causes, some sociocultural factors should be considered. The first issue is determining how tolerant a society is to of animal abuse, which is a factor that varies greatly between countries and regions, and also how important is for this society the conservation of the environment and natural resources. In Spain, certain forms of animal abuse are extensive and even accounted for in the legal system, such as the use of animals during the approximately 20,000 popular festivals held each year throughout the country that often results in the death or torture of different types of animals, mainly bulls, cows and calves. Therefore, in many Spanish regions, there is a social habituation to certain forms of animal abuse (Chew and Armstrong, 2001). Furthermore the presence of abandoned animals in large numbers without effective control measures performed by the administration creates numerous problems for ranchers, hunters, farmers, and in

\section{Table 3}

"Potential of lethality" of carbofuran and aldicarb.

\begin{tabular}{llc}
\hline & 5 g of product & \\
\cline { 2 - 3 } & Species & $\begin{array}{c}\text { Number of animals } \\
\text { that could die }\end{array}$ \\
\hline Carbofuran & Common Buzzard (Buteo buteo) & 926 \\
& Common Kestrel (Falco tinnunculus) & 4167 \\
& Cat (Felis silvestris) & 257 \\
Aldicarb & Human being & 13 \\
& Common Buzzard (Buteo buteo) & 11,211 \\
& Common Kestrel (Falco tinnunculus) & 50,012 \\
& Cat (Felis silvestris) & 3246 \\
& Human being & 154 \\
\hline
\end{tabular}


residential and tourist areas of the country. Poison sometimes becomes the quickest option to end the problem. Besides, it has been recently reported that the Canary Islands and the Balearic Islands are regions in Spain where the rate of abandoned animals is higher ( $>60$ dogs and cats / 10,000 inhabitants) (Segú et al., 2010) and among the highest rates in Europe compared with countries where data have been reported (Tasker, 2008). Additionally, other factors may be influencing the intentional use of pesticides against animals, including a high accessibility to toxic pesticides, or the lack of controlling the possession of prohibited chemicals. This ease of access to chemicals is coupled with a certain sense of impunity for poisoners because, although the crime of using poison to control predators is included in the European legislation (including Spain), material and human resources devoted to criminal prosecution are usually lacking. Recently the "Strategy for eradication of illegal use of poison in the non-urban areas of the Canary Islands" has been approved by the regional government with the aim of prosecuting this illegal activity (BOC, 2014) but to date there have not been convictions for this crime in the Canaries.

Several of the above cited circumstances simultaneously concur in many European regions and are especially relevant in the Canary Islands, where this study was performed. Therefore, authorities should take different measures to correct the circumstances that motivate the intentional poisoning of animals to curb, or at least minimise, this serious problem that severely threatens biodiversity, animal welfare and public health.

\section{Conclusions}

We present the results of a prospective analysis of all cases of poisoning of wild and domestic animals that have occurred over a period of 32 months in the archipelago of the Canary Islands. Our preliminary experience seemed to indicate that there was a high involvement of pesticides in these cases and, more worryingly, the involvement of prohibited pesticides. In order to test this hypothesis we designed this study including only those cases in which there was direct evidence of intentional poisoning, or cases of unknown origin, being expressly excluded those cases with a clear accidental aetiology. Our results indicated that 117 animals were intentionally poisoned, which represents $52.5 \%$ of the animals that were included in the study, and that frequently wildlife was affected animals (mainly birds of prey and scavengers). The set of results presented in this study is the highest reported to date in any territory of the European Union. Our study confirms the involvement of banned pesticides is high in this archipelago (mainly carbofuran and aldicarb), as this product was identified in $75 \%$ of animals and $97 \%$ of the baits. This set of results is extremely worrying, as it implies that there is still access to these products of extremely high toxicity, which are being used in an uncontrolled manner. This is particularly acute in a territory such as the Canary Islands, where there are 11 protected natural areas with the highest level of protection under the European Union (4 National Parks and 7 Parks Rural), so that the high use of poison poses a great risk to biodiversity conservation. It is imperative that the authorities allocate material and human resources to the prosecution of this crime, and the parallel development of education and awareness campaigns in order to minimize environmental impact of this illegal and harmful practice.

Supplementary data to this article can be found online at http://dx. doi.org/10.1016/j.scitotenv.2014.10.093.

\section{Conflicts of interest}

The authors declare no conflicts of interest.

\section{Acknowledgements}

The authors would like to thank the Canary Islands Government (Dirección General de Protección de la Naturaleza, Gobierno de
Canarias) for their financial support. Authors are also thanked to veterinarians of the Wildlife Recovery Centers of Gran Canaria (Pascual Calabuig and Dolores Estévez) and Tenerife (Santiago Mayans) for their collaboration in the necropsies and in the sampling of the animals and also to Mrs. María de los Reyes Suárez Hanna for her technical assistance.

\section{References}

Berny P. Pesticides and the intoxication of wild animals. J Vet Pharmacol Ther 2007;30: 93-100.

Berny P, Gaillet JR. Acute poisoning of Red Kites (Milvus milvus) in France: data from the Sagir network. J Wildl Dis 2008:44:417-26.

Berny P, Caloni F, Croubels S, Sachana M, Vandenbroucke V, Davanzo F, et al. Animal poisoning in Europe. Part 2: Companion animals. Vet J 2010;183:255-9.

BOC. Orden 1489, de 28 de marzo de 2014, por el que se aprueba la estrategia para la erradicación del uso ilegal de veneno en el medio no urbano de Canarias. Boletin Oficial de Canarias (BOC) n 70, de 9 de abril; 2014. p. 9252-324.

BOE. Decreto de 11/08/1953 por el que se declara obligatoria la organización de las Juntas Provinciales de Extinción de Animales Dañinos y Protección a la Caza. BOE; 1953. p. 5605-6 [11 de agosto].

Brown PM, Turnbull G, Charman S, Charlton AJ, Jones A. Analytical methods used in the United Kingdom Wildlife Incident Investigation Scheme for the detection of animal poisoning by pesticides. J AOAC Int 2005;88:204-20.

Chew M, Armstrong RM. Bullfighting in Barcelona. Med J Aust 2001;175:573-4.

De la Bodega D. Sustancias que provocan el envenenamiento de la fauna silvestre. Estudio técnicoSEO/Birdlife Report; 2012.

EC. Council Decision of 18 March 2003 concerning the non-inclusion of aldicarb in Annex I to Council Directive 91/414/EEC and the withdrawal of authorisations for plant protection products containing this active substance. Off J Eur Union 22/03/2003; L 076: 0021-4.

EC. Commission Regulation (EC) No 199/2006 of 19 December 2006 amending Regulation (EC) No 466/2001 setting maximum levels for certain contaminants in foodstuffs as regards dioxins and dioxin-like PCBs. Off J Eur Union 20/12/2006:L 364:0005-24.

EC. Commission Decision of 13 June 2007 concerning the non-inclusion of carbofuran in Annex I to Council Directive 91/414/EEC and the withdrawal of authorisations for plant protection products containing that substance. Off J Eur Union 16/06/2007; L 156:0030-1.

Eddleston M, Karalliedde L, Buckley N, Fernando R, Hutchinson G, Isbister G, et al. Pesticide poisoning in the developing world-a minimum pesticides list. Lancet 2002; 360:1163-7.

Fajardo I, Ruiz A, Zorrilla I, Valero A, Fernández I, Sáez E, et al. Use os specialised canine units to detect poisoned baits and recover forensic evidence in Andalucía (Southern Spain). In: Richards N, editor. Carbofuran and wildlife poisoning: global perspectives and forensic approaches. John Wiley \& Sons, Inc.; 2012

González LM, Margalida A, Mañosa S, Sánchez R, Oria J, Molina JI, et al. Causes and spatiotemporale variations of non-natural mortality in the vulnerable Spanish imperial eagle (Aquila adalberti) during a recovery period. Oryx 2007:41:495-502.

Guitart R, Manosa S, Guerrero X, Mateo R. Animal poisonings: the 10-year experience of a veterinary analytical toxicology laboratory. Vet Hum Toxicol 1999;41:331-5.

Guitart R, Croubels S, Caloni F, Sachana M, Davanzo F, Vandenbroucke V, et al. Animal poisoning in Europe. Part 1: Farm livestock and poultry. Vet J 2010a;183:249-54.

Guitart R, Sachana M, Caloni F, Croubels S, Vandenbroucke V, Berny P. Animal poisoning in Europe. Part 3: Wildlife. Vet J 2010b;183:260-5.

Hernandez M, Margalida A. Pesticide abuse in Europe: effects on the Cinereous vulture (Aegypius monachus) population in Spain. Ecotoxicology 2008;17:264-72.

Hernández M, Margalida A. Poison-related mortality effects in the endangered Egyptian vulture (Neophron percnopterus) population in Spain. Eur J Wildl Res 2009;55: 415-23.

Hornfeldt CS, Murphy MJ. Poisonings in animals: the 1993-1994 report of the American Association of Poison Control Centers. Vet Hum Toxicol 1997;39:361-5.

Kervegant M, Merigot L, Glaizal M, Schmitt C, Tichadou L, de Haro L. Paraquat poisonings in France during the European ban: experience of the Poison Control Center in Marseille. J Med Toxicol 2013;9:144-7.

Kwon YK, Wee SH, Kim JH. Pesticide poisoning events in wild birds in Korea from 1998 to 2002. J Wildl Dis 2004;40:737-40.

Litchfield MH. Estimates of acute pesticide poisoning in agricultural workers in less developed countries. Toxicol Rev 2005;24:271-8.

Luzardo OP, Ruiz-Suarez N, Valeron PF, Camacho M, Zumbado M, Henriquez-Hernandez LA, et al. Methodology for the identification of 117 pesticides commonly involved in the poisoning of wildlife using GC-MS-MS and LC-MS-MS. J Anal Toxicol 2014 38:155-63.

Margalida A, Heredia R, Razin M, Hernández M. Sources of variation in mortality of the bearded vulture Gypaetus barbatus in Europe. Bird Conserv Int 2008;18:1-10.

Martínez-Haro M, Mateo R, Guitart R, Soler-Rodríguez F, Pérez-López M, GarcíaFernández AJ. Relationship of the toxicity of pesticide formulations and their commercial restrictions with the frequency of animal poisonings. Ecotoxicol Environ Saf 2008;69:396-402

Mineau P, Baril A, Collins BT, Duffe J, Joerman G, Luttik R. Pesticide acute toxicity reference values for birds. Rev Environ Contam Toxicol 2001;170:13-74.

Motas-Guzman M, Marla-Mojica P, Romero D, Martinez-Lopez E, Garcia-Fernandez AJ Intentional poisoning of animals in southeastern Spain: a review of the veterinary toxicology service from Murcia, Spain. Vet Hum Toxicol 2003;45:47-50. 
Ogada DL. The power of poison: pesticide poisoning of Africa's wildlife. Ann N Y Acad Sci 2014;1322:1-20.

Segú JL, Amblàs S, Longare E, Gabriel M, Gall L, Martínez M, et al. Estudio Fundación Affinity sobre el abandono de animales de compañía. Fundación Affinity; 2010.

Slaninova A, Smutna M, Modra H, Svobodova Z. A review: oxidative stress in fish induced by pesticides. Neuro Endocrinol Lett 2009;30(Suppl. 1):2-12.
Tasker L. Stray Animal Control Practices (Europe). A report into the strategies for controlling stray dog and cat populations adopted in thirty-one countries. World Society fo the Protection of Animals; 2008.

Wagner N, Reichenbecher W, Teichmann H, Tappeser B, Lotters S. Questions concerning the potential impact of glyphosate-based herbicides on amphibians. Environ Toxicol Chem 2013;32:1688-700. 